\title{
The 'dying' offer Rule in European Contract Law
}

\author{
Gregor ChristandL*
}

Abstract: Does the offeror's or the offeree's death terminate a contractual offer? While the PECL and the DCFR remain silent on the issue, recent reform proposals of the law of obligations presented in France, Spain and the Czech Republic suggest diverging solutions. By analysing the historical foundations and the functioning of the existing rules in selected European legal systems, this Article aims to detect the common core of the differing national rules and finally suggests a formulation for a future European contract law.

Résumé: Est-ce que le décès de l'offrant ou du destinataire de l'offre rend l'offre caduque? Tandis que les principes $d u$ droit européen des contrats et le projet de cadre commun de référence demeurent silencieux sur la question, de récentes propositions de réforme $d u$ droit des obligations présentées en France, en Espagne et dans la République tchèque suggèrent des solutions divergentes. En analysant les fondations historiques et le fonctionnement des règles actuelles dans quelques systèmes juridiques européens sélectionnés, cet article essaie de définir le noyau commun des règles nationales différentes et suggère finalement une formulation pour un futur droit européen des contrats.

Zusammenfassung: Gebt mit dem Tod des Offerenten oder des Angebotsempfängers ein Vertragsangebot unter? Während die PECL und der DCFR diesbezüglich keine Regelung enthalten, wurden in jüngsten Schuldrechtsreformvorschlägen in Frankreich, Spanien und Tschechien abweichende Lösungen vorgeschlagen. Auf der Grundlage einer historischen und funktionalen Analyse der geltenden Regelungen in ausgewäblten europäischen Rechtsordnungen bemüht sich dieser Beitrag den gemeinsamen Kern der unterschiedlichen nationalen Bestimmungen offenzulegen und unternimmt schließlich den Versuch, einen Regelungsvorschlag für ein künftiges Europäisches Vertragsrecht zu formulieren.

\section{Introduction}

Suppose that A offers B his car at a certain price but some days before B decides to accept the offer, A dies. Can B still accept with the effect that the contract is concluded between him and A's heirs? And what about the reverse case in which the offeree B dies before having accepted A's offer. Can B's heirs instead of $\mathrm{B}$ accept and thereby enter the contract? It is generally argued that similar questions arise when a person after making or prior to accepting an

* Dr. Gregor Christandl, LL.M. (Yale), Wissenschaftlicher Referent, Max Planck Institute for Comparative and International Private Law, Hamburg. I am thankful for the stimulating discussion in an Aktuelle Stunde at the Max Planck Institute for Comparative and International Private Law, Hamburg, where this paper was presented in April 2011. 
offer is declared legally incompetent. Does the offer lapse in these cases or can it still be accepted?

Recent reform proposals of the law of obligations presented in France, Spain and the Czech Republic addressed this issue, suggesting diverging solutions. While the French proposal ${ }^{1}$ remains faithful to the traditional 'dying' offer rule, ${ }^{2}$ according to which an offer is generally considered to lapse with the death or incapacitation of the offeror or offeree, the Spanish ${ }^{3}$ and implicitly the $\mathrm{Czech}^{4}$ draft adopt the opposite rule according to which offers are generally presumed to remain effective regardless of the supervening death or incapacitation of either party.

A first glance at some European legal systems reveals that these divergences between the different proposals reflect the general state of European contract law on the issue. While some legal systems generally follow the 'dying' offer

1 P. Catala, Avant-projet de réforme du droit des obligations et de la prescription (Paris, Documentation française: 2006) 83: art 1105-3: 'L'offre devient caduque à défaut d'acceptation dans le délai fixé par son auteur, ainsi qu'en cas d'incapacité ou de décès de celui-ci survenu avant toute acceptation. Elle tombe également lorsque son destinataire la refuse.' - 'An offer lapses if it is not accepted within the period fixed by the person who makes it or in the case of his incapacity or death before its acceptance. It is also extinguished if the offeree rejects it.' (English translation by J. Cartwright and S. Whittaker, in J. Cartwright, S. Vogenauer and S. Whittaker (eds), Reforming the French Law of Obligations [Oxford: Hart Publishing, 2009] 449 ff, 635).

2 The expression is used by V.D. Ricks, 'The Death of Offers' 79 Indiana Law Journal (2004) 667-709. Because of its conciseness and notwithstanding its imprecision (while the offeror or offeree dies, an offer can obviously not die) it is also used in this article.

3 Comisión General de Codificación, Propuesta de Modernización del Código civil en materia de Obligaciones y Contratos, Boletín de Informacion, Ministerio de Justicia, Enero 2009, Art. 1256: 'Ni la oferta ni la aceptación pierden su eficacia por la muerte o por la incapacidad sobrevenida de una de las partes ni tampoco por la extinción de las facultades representativas de quien las hizo. (2) Se exceptúan los casos en que resulte lo contrario de la naturaleza del negocio o de otras circunstancias.' 'An offer and an acceptance do not lose their effects in case of supervening death or incapacity of one of the parties nor in case of extinction of the power of agency of the person who declared the offer or acceptance. (2) This rule does not apply to those cases in which the contrary appears from the nature of the transaction or other circumstances.'

4 While the current Czech codification does not contain any rule on the effects of death or incapacitation on a pending offer, the most recent draft for a new civil code states in $\$ 1672(2)$ that an offer lapses with the death or incapacitation of either party if this can be inferred either from the offer itself or the nature and purpose of the proposed contract. Hence, the general rule according to the new Czech draft is that the offer does not lapse, except in the cases described by the provision. ‘ $\$ 1672(1)$ Je-li nabídka odmítnuta, zaniká účinností nabídky. (2) Zemře-li některá ze stran, nebo pozbude-li svéprávnosti uzavřít smlouvu, nabídka zanikne, pokud je to zřejmé z nabídky samé nebo z povahy a účelu navrhované smlouvy.' The author thanks Petra Pipkóva (Institute for European Tort Law, Vienna) for the translation. 
rule (France, Italy, Spain, England), ${ }^{5}$ others allow the offer to remain unaffected by the death or incapacitation of one of the parties (Germany, Austria, Portugal, Netherlands). ${ }^{6}$

Considering these diverging basic approaches in national European contract laws, one might expect that the Principles of European Contract Law (PECL) or the Draft Common Frame of Reference (DCFR) would have provided a special rule solving the issue uniformly on the basis of general principles. However, neither the Commission on European Contract Law (PECL) ${ }^{7}$ nor the Study Group on a European Civil Code (DCFR) provided such a rule. The reasons for this gap remain in the dark. It doesn't seem unlikely, though, that both the Commission on European Contract Law and the Study Group on a European Civil Code followed the Working Group on the International Sale of Goods which explicitly decided against a rule on the issue, ${ }^{8}$ arguing that death and incapacity are of minimal importance in international trade and that questions of contractual capacity are not covered by the Convention on Con-

5 The Italian rule is derived e contrario from art 1329 p 2, 1330 Codice civile (Italian Civil Code); France and Spain do not dispose of any specific provision on the issue, but their courts tend to follow the 'dying' offer rule. See on this rule in the United States: Restatement (Second) of Contracts $\$ 48$ (1981); for an overview with ample references to literature and case law see: Ricks, n 2 above. See also: A.E. Papale, 'The Effect of Death in PreContract Negotiations' 4 Loyola Law Review (1948) 109-136; A.L. Corbin, 'Offer and Acceptance, and Some of the Resulting Legal Relations’ 26 Yale Law Journal (1917) 169206.

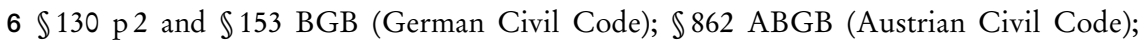
art 6:222 BWB (Dutch Civil Code); art 226 p 1 Código civil (Portuguese Civil Code).

7 See, however, the French revision of the PECL which adds a third paragraph to art 2:202 (in the revision art 2:203) according to which the death or incapacitation of the offeror does not by itself terminate the offer ('Le décès ou l'incapacité de l'offrant ne met pas à lui seul un terme à l'offre.'). Association Henri Capitan, Principes contractuels communs, Projet de cadre commun de référence (Paris: Sociéte de législation comparée, 2008) 793. The same rule is adopted by the Draft Proposal for a European Contract Code (Academy of European Private Lawyers), art 18: 'In the event of the death or supervening incapacity of either the offeror or the offeree, the offer or acceptance do not become ineffective unless so justified by the nature of the transaction, or the circumstances.' See http://www.acca demiagiusprivatistieuropei.it/newdoc/Norme\%20_Libro\%20I-inglese_.pdf.

8 Report of the Working Group on the International Sale of Goods on the Work of its ninth session (Geneva, 19-30 September 1977, Doc A/CN.9/142), in Yearbook of the United Nations Commission on International Trade Law, vol IX, 1978, 81 (n $279 \mathrm{ff}$ ). The previous art 11 of the proposal was deleted: 'The formation of the contract is not affected by the death of one of the parties or by his becoming physically or mentally incapable of contracting before the acceptance becomes effective, unless the contrary results from the intention of the parties, usage or the nature of the transaction.' Draft convention on the formation of contracts for the international sale of goods as approved or deferred for further consideration by Working Group on the International Sale of Goods at its eighth session, art 11, in Yearbook of the United Nations Commission on International Trade Law, vol VIII, 1977, 90. 
tracts for the International Sale of Goods (CISG). Just like the CISG, also the UNIDROIT Principles of International Commercial Contracts (UNIDROIT PICC) lack a special provision on this question.

This Article analyses ${ }^{9}$ the existing rules on the issue as they are applied in selected European legal systems (Austria, England, France, Germany, Italy, the Netherlands, Spain, and Portugal) in order to establish to what extent the different basic approaches really lead to different solutions in the law in action. A brief analysis of the historical origins of the 'dying' offer rule in the first part (II) of the article will be followed by an examination of the general rules applied in selected European legal systems (III). In the light of the differing approaches in Europe, some reasons for and against the 'dying' offer rule will be evaluated in the third part (IV). The findings gathered will then allow us to address the questions whether a future European contract law should contain a rule on the issue as well as what the scope and what the specific content of such a rule should be $(\mathrm{V})$. The article concludes by suggesting a formulation for a rule which reflects the common core of European contract law (VI).

\section{The origins of the 'dying' offer rule}

The problem of supervening death or incapacitation of one of the parties to a future contract is most likely to occur in case of contracts concluded between absent parties. While Roman law explicitly allowed a sales contract to be concluded inter absentes, ${ }^{10}$ it did not provide any rules on the effects of unilateral declarations (offer, acceptance) prior to the conclusion of a contract. Hence, the central question faced by medieval jurists commenting on this way of entering a contract was whether the offeror's intention had to persist beyond the moment of declaration of the offer or whether the offer became independent from the offeror's subjective intention once it was declared. With regard to agency law, ${ }^{11}$ Bartolo da Sassoferrato (1314-1357) argued that the

9 For brief comparative overviews on this issue see: R.B. Schlesinger, Formation of Contracts, vol I (Dobbs Ferry: Oceana Publ, 1968) 116; H. Kötz and A. Flessner, European Contract Law (Oxford: Clarendon Press, 1998) 24f; with ample references to legal sources in different national systems F. Ranieri, Europäisches Obligationenrecht (3rd ed, Wien/New York: Springer, 2009) $281 \mathrm{ff}$.

10 Paulus, D 18.1.1.2: 'Est autem emptio iuris gentium, et ideo consensu peragitur et inter absentes contrahi potest et per nuntium et per litteras.' Gaius, D 44.7.2.2: 'Unde inter absentes quoque talia negotia contrahuntur, veluti per epistulam vel per nuntium.'

11 Bartolo da Sassoferrato [Bartolus de Saxoferrato], Commentaria, D 15,4,1 (quod iussu). The 'dying' offer rule can be traced back to agency law, especially to D 39.5.19.3 where Ulpian refers to the case in which the principal dies before the agent who according to his task donates something to a third person. Ulpian distinguishes the case in which the agent knows about the death of the principal when he undertakes his task from the case 
sender's intention is not fixed in the letter because a letter is a mere instrument that serves to inform the addressee about the sender's intention (quia tunc nuncius, vel epistula nudum praestat ministerium) and can therefore be revoked until the offeree accepts with the effect that notwithstanding the meeting of the intention declared in the letter and the addressee's acceptance no consent is formed (deficit eius consensus). ${ }^{12}$ Thus, Bartolo had set the basis for the other famous commentator of the 14th century Baldo degli Ubaldi (13191400) who, still with regard to agency law, contributed to the formulation of the 'dying' offer rule stating that if death or insanity occur before the letter reaches the offeree (si antequam pervenit nuncius vel epistula moriatur mittens vel efficiat furiosus) no contract can be concluded, since the offeror's intention does not last long enough (tunc non contrabitur obligatio per nuncium, vel epistolam quia non durat voluntas, nec intervenit consensus). ${ }^{13}$ Giovanni Pietro Sordi (?-1598) developed the rule further, stating more in general that an offer sent by letter is terminated by death because once the offeror is dead an agreement can no longer be reached ('epistolam vel nuncium obligare non posset scribentem, vel mittentem, si is decedat antequam ad cum pervenerint, cum quo erat contrabendum, quia cum per mortem deficiat scribentis consensus, non potest dici, quod eius scriptura loquatur'). ${ }^{14}$

So the basic idea behind the 'dying' offer rule developed by medieval commentators is that a contract cannot be concluded unless both parties express their consent simultaneously (Pactum autem non valet, nisi interveniat simultaneus consensus, ut dictum est. $\left.{ }^{15}\right)$. Since a simultaneous consent is de facto impossible with regard to a contract concluded between absent parties, the commentators considered the offeror to be actually speaking to the offeree through the letter. This, of course, required that the offeror was living ${ }^{16}$ and legally competent at the moment when the offeree accepted the offer sent by

in which he doesn't, allowing the agent to sue the heirs of the principal only in the second case: 'Si autem mandavero tibi, ut pecuniam Titio des, cui donare volebam, et tu ignorans me mortuum hoc feceris, habebis adversus heredes meos mandati actionem: si sciens, non habebis.' From this rule concerning the problem of termination of agency (and thus of a contract) in case of death of one party, the medieval commentators derived a more general rule according to which the intention to legally bind oneself by a contract transmitted by a messenger or a letter needs to persist until the contract is concluded. If one party dies or revokes his/her intention before the contract is concluded, no consent will be formed. Bartolo argues: 'Et ideo ubi paenitet mandantem, statim deficit eius consensus. Quod ergo postea sequit, non potest effectum fortiri.’ Bartolo da Sassoferrato, ibidem.

12 Bartolo da Sassoferrato, n 11 above.

13 Baldo degli Ubaldi [Baldus], Commentaria, D 17.1.1.

14 Giovanni Pietro Sordi [Iohannes Petrus Surdus], Consilia, n 136, 46.

15 Giovanni Pietro Sordi, n 14 above, n 136, 52.

16 'Quia mortuo eo non potest dici, quod scritpura eius loquatur': Alexander Tartagna de Imola, Consilia, vol 5, cons 24, 9. 
letter. Sordi put this idea in a nutshell, stating that the letter allows the absent to talk to the present party, but a dead person could not speak: 'per epistolam enim prasens videtur absenti loqui, sed mortuus non loquitur'. ${ }^{17}$

\section{The rule in modern European contract law}

The 'dying' offer rule is still dominant in several European legal systems. However, the following brief analysis of the law in action in some of these countries will illustrate that the traditional ius commune rule has been largely transformed into a prima facie rule that no longer enjoys absolute application.

\section{Legal systems following the 'dying' offer rule}

\section{a) France}

As is well known, the French codification does not contain any rules on the formation of contracts. Accordingly, the Code Civil remains silent as to the effects of death or incapacitation on an offer before a contract is concluded. However, French authors and courts have traditionally held that an offer lapses at the moment of the offeror's death or incapacitation, ${ }^{18}$ because the offer is considered to remain linked to the subjective intention of the offeror and must therefore end with the offeror himself. ${ }^{19}$ This rule was first adopted in French law by Pothier who on this question decided to follow the traditional ius commune doctrine established by Bartolo..$^{20}$

17 Giovanni Pietro Sordi, n 14 above, n 136, 48.

18 See J. Ghestin, Traité de droit civil - La formation du contrat (3th ed, Paris: Librairie générale de droit et de jurisprudence, 1993) 280, citing the following two decisions: Cass soc 14. 4.1961, JCP 1961, II, 12260; Cass civ 1.5.1894, D 1895, 1, 69. This view is deeply rooted in the French literature: C.S. Zachariae, C. Aubry and C. Rau, Cours de droit civil français (Paris: Marchal \& Billard, 1842) vol 1, 381, n 3 with further references; P.A. Merlin, Répertoire universel et raisonné de jurisprudence (4th ed, Paris, 1815) t 14, $507 \mathrm{ff}$. For an ample discussion of the problem with copious references see R. Chabaan, La caducité des actes juridiques (Paris: LGDJ, 2006) $260 \mathrm{ff}$.

19 'En effet, une telle offre - qui peut tourjours être révoquée - demeure diretecement liée à la volonté de son auteur et doit donc disparaître en même temps que celui-ci.' J. Flour, J.L. Aubert and É. Savaux, Les obligations 1. L'acte juridique (13 ${ }^{\text {rd }} \mathrm{ed}$, Paris: Dalloz-Sirey, 2008) $113 \mathrm{f}$.

20 R.J. Pothier, Traité du contrat de vente (Paris: 1781) vol 1,30 f: 'Dans le contrat de vente, de même que dans les autres contrats, le consentement des parties peut intervenir non seulement entre présens, mais entre absens, par lettres, ou par un entremetteur, per epistolam aut per nuncium. Pour que le consentement intervienne en ce cas, il faut que la volonté de la partie qui a écrit à l'autre pour lui proposer le marché, ait préservé jusqu'au temps auquel sa lettre sera parvenue à l'autre partie, \& auquel l'autre partie aura déclaré qu'elle acceptoit le marché. Cette volonté est présumée avoir persévéré tant qu'il ne paroît rien de contraire: 
When in 1983, the Cour de Cassation ${ }^{21}$ decided that death alone cannot terminate an offer, it seemed as if the long standing 'dying' offer rule had been abruptly abandoned. While according to the prevailing opinion this decision had to be interpreted as a clear rejection of both the 'dying' offer rule and the will theory, ${ }^{22}$ it was also argued that the true reason for this decision (confirmed in another case decided by the Cour de Cassation in 199723) was that the offer had been made jointly by two persons of whom only one had died. ${ }^{24}$ In 1989, the Cour de Cassation ${ }^{25}$ returned to the issue stating in an obiter dictum that 'l'offre devient caduque par le décès de son auteur', thus confirming the continuing validity of the 'dying' offer rule in French law. ${ }^{26}$ In the case where the offeree dies or is declared incompetent, the offer is also considered to lapse, ${ }^{27}$ whereas irrevocable offers generally remain unaffected by death or incapacitation. ${ }^{28}$

While the current rule in French law is not entirely clear, the first proposal for a reform of the French law of obligations (avant-projet Catala) explicitly confirms the traditional 'dying' offer rule. ${ }^{29}$ Also the more recent Projet

mais si j'ai écrit à un marchand de Livourne une lettre par laquelle je lui proposois de lui vendre une certaine partie de marchandises pour un certain prix, \& qu'avant que ma lettre ait pu lui parvenir, je lui en aie écrit une seconde, par laquelle je lui marquois que ne vouluois plus cette emplette; ou qu'avant ce temps je sois mort, ou que j'ait perdue l'usage de ma raison; quoique ce marchand de Livourne, au reçu de ma lettre, ignorant ou mon changement de volonté, ou ma mort, ou ma démence, ait fait réponse qu'il acceptoit le marché proposé; néanmoins il ne sera intervenu entre nous aucun contrat de vente: car ma volonté n'ayant pas persévéré jusqu'au temps auquel ce marchand a reçu ma lettre, \& accepté la proposition qu'elle contenoit, il ne s'est pas rencontré un consentement ou concours de nos volontés nécessaires pour former le contrat de vente. C'est l'avis de Barthole \& des autres Docteurs cités par Bruneman, ad l. I, ff., de contr. empt, qui ont rejeté avec raison l'avis contraire de la glose, ad dictam legem.'

21 Cass $^{\text {e }}$ civ 9.11.1983, Bull civ III, n 222, 168. This view was affirmed by Conseil d'État, 5.10.1988, JCP 1989, II, 21182.

22 'Sur un plan général, il traduisait l'abandon des analyses qui voient dans le consentement "le concours conscient de deux volontés qui, réciproquement, se connaissent", ou même, plus simplement, la coexistence de deux volontés concordantes.' Ghestin, n 18 above, 280.

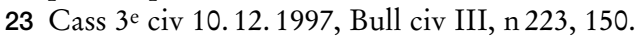

24 See Chabaan, n 18 above, 264: 'La transmission de l'offre est exceptionnellement admise pour le seul cas de l'offre conjointe, dans l'hypothèse de survie de l'un des offrants. Contrairement à ce que semblent déduire certains commentateurs, la Cour ne se fonde pas sur l'existence d'un délai ou sur l'irrévocabilité de l'offre, pour admettre sa survie au décès de l'un des coauteurs. En principe, l'offre est intransmissible à cause de mort. Il y est fait exception dans la seule hypothèse de l'offre conjointe.'

25 Cass $3^{\mathrm{e}}$ civ 10.5.1989, Bull civ III, $\mathrm{n} 109$.

26 Flour, Aubert and Savaux, n 19 above, 114; for criticism: Ghestin, n 18 above, 281.

27 Flour, Aubert and Savaux, n 19 above, 113, citing Cass 20.7.1846, D 1846, 1, 335.

28 Flour, Aubert and Savaux, n 19 above, 113, citing Cass 3e civ 10.12.1997, Bull civ III, n 223; contra: Chabaan, n 18 above, 264. 'Qu'elle soit ou non assortie d'un délai, l'offre est un acte juridique unilatéral intrasmissible à cause de mort.'

29 See $\mathrm{n} 1$. This rule is an example for the conservative character of the draft which was 
Terré30 as well as the Projet de la chancellerie ${ }^{31}$ espouse this rule, arguing that it did not seem appropriate to enforce the formation of a contract in case of death or incapacity. ${ }^{32}$

\section{b) Italy}

Under the influence of French authors and the ius commune, the 'dying' offer rule was already followed - though not without controversy ${ }^{33}$ - under the Italian codification of $1865^{34}$ which like the French code did not contain any provisions neither on the formation of contracts nor on the effects of death or incapacitation on a pending offer. With the Italian Codice Civile of 1942 specific rules on the formation of contracts were introduced. The effects of death or incapacitation ${ }^{35}$ on a pending offer are now derived by an argumentum e contrario from Articles 1329(2) and 1330 Codice Civile. ${ }^{36}$

developed according to the principle 'conserver tout ce qu'il n'est pas nécessaire de détruire' and generally does not take into consideration foreign legal developments. According to Stefan Vogenauer '[...] the Aavant-projet displays a major defect for a project that is explicitly designed to influence the international contract law discourse: an almost total absence of comparative reasoning.' S. Vogenauer, 'The Anvant-projet de réforme', in Cartwright, Vogenauer and Whittaker (eds), n 1 above, 21.

30 F. Terré, Pour une réforme du droit des contrats (Paris: Dalloz, 2008) art 16.

31 In 2008, the Projet de la chancellerie was presented by the French Ministry of Justice as the first legislative reform proposal. See for a brief overview Vogenauer, n 29 above, $18 \mathrm{f}$. The most recent version of the draft of May 2009 maintained this rule (http://www. dimitri-houtcieff.fr/files/projet DACS modifié mai 2009-numéroté.pdf).

32 'Il n'est pas en effet apparu opportun de forcer à la formation d'un contrat en cas de révocation illégitime d'une offre faite, de même en cas d'incapacité ou de décès de son auteur.' See for an unofficial version of the draft with an explanatory introduction: http:// www.dimitri-houtcieff.fr/files/projet_droit_des_contrats_blog8_2_.pdf.

33 For an overview with ample references see A. Montel, Successione nella proposta, in Annuario di diritto comparato e di studi legislativi (1933) vol 8, 3, 139: 'Grave e dibattuta questione è quella della trasmissibilità della proposta agli eredi del proponente.'

34 Cass 28. 5. 1926, Foro it (1927) I, 3. For further references see G. Scaduto, 'La successione nella proposta' Rivista diritto commerciale (1928) I, 121-127; contra G. Giorgi, Teoria delle obbligazioni, vol 3 (Firenze, 1925) 297; P. Bonfante, 'La successione nella promessa' Rivista diritto commerciale (1927) I, 1-17; A. Candian, 'Indole recettizia della revoca della proposta e dell'accettazione' Rivista diritto commerciale (1927), 379-394, 387 ff; Montel, n 33 above, 3, 139-141.

35 Incapacitation only refers to a judicial declaration of incompetence (interdizione, inabilitazione) because of mental disorders. According to the prevaling opinion it does not refer to incompetence due to bankruptcy or to cases of temporary mental disorders (incapacità naturale). R. Scognamiglio, Commentario del Codice civile - Dei contratti in generale Art. 1321-1352 (Bologna: Zanichelli, 1970) 138; V. Roppo, Il contratto (Milan: Giuffré, 2001) 147; R. Sacco, in R. Sacco and G. De Nova, Il contratto (Torino: UTET, 2004) $217 \mathrm{f}$.

36 See eg Roppo, n 35 above, 146. 
Pursuant to Article 1329(2) Codice Civile an irrevocable offer remains unaffected by death or supervening incapacitation of the offeror, unless this effect is excluded by the nature of the transaction or other circumstances. ${ }^{37}$ The same rule applies to a revocable offer or acceptance made by an entrepreneur (unless he is a small entrepreneur) in the operation of his business (Article 1330). ${ }^{38}$ So if an offer is irrevocable or the offer comes from an entrepreneur, the contract will be concluded even if the offeror dies. ${ }^{39}$ Only the nature of the transaction or other special circumstances can prevent the transfer of the offer to the offeror's heirs. These two provisions constitute exceptions that confirm the underlying general rule according to which in Italian law both the offer and the acceptance are regularly terminated at the moment of the offeror's death. ${ }^{40}$ Therefore no contract will usually be formed if, the offeror dies or is declared legally incompetent before the acceptance reaches the offeror's address. In the absence of a specific rule, there also seems to be agreement that the offeree's position generally cannot be transferred to his or her heirs so that the offer also lapses with the death or incapacitation of the offeree. ${ }^{41}$

\section{c) Spain}

Like the French Code Civil, also the Spanish Código civil lacks rules on the formation of contract and therefore does not provide for the effects of death or incapacitation on offers. Traditionally, however, Spanish authors have followed the 'dying' offer rule ${ }^{42}$ with the exceptions established by the Italian

37 'Art. 1329 Proposta irrevocabile (1) Se il proponente si è obbligato a mantenere ferma la proposta per un certo tempo, la revoca è senza effetto. (2) Nell'ipotesi prevista dal comma precedente, la morte o la sopravvenuta incapacità del proponente non toglie efficacia alla proposta, salvo che la natura dell'affare o altre circostanze escludano tale efficacia.'

38 'Art. 1330 Morte o incapacità dell'imprenditore - La proposta o l'accettazione, quando è fatta dall'imprenditore nell'esercizio della sua impresa, non perde efficacia se l'imprenditore muore o diviene incapace prima della conclusione del contratto, salvo che si tratti di piccoli imprenditori o che diversamente risulti dalla natura dell'affare o da altre circostanze.'

39 According to art 1325(1) Codice civile a contract is concluded when the offeror knows about the acceptance of the offeree. Knowledge of the acceptance is presumed according to art 1335 Codice civile once the acceptance has reached the offeror's address, unless he or she can prove that without his fault he could not know about the offer.

40 Scognamiglio, n 35 above, 137; Sacco, n 35 above, 216; Roppo, n 35 above, 146.

41 Roppo, n 35 above, 148; Scognamiglio, n 35 above, 137.

42 M.C. Payeras, in Ministerio de Justicia, Comentario al Código Civil, vol II, Art. 1.262, 449: 'La doctrina en torno al CC espanol ha venido sosteniendo, mayoritariamente, que la muerte o la incapacidad sobrevendia del oferente, previas a la aceptación, producen la extinción de la oferta contractual. O sea, la intransmisibilidad mortis causa de la oferta.' See also who defends the 'dying' offer rule against criticism: L. Díez-Picazo, Fundamen- 
Civil Code of $1942 .{ }^{43}$ Therefore, both in case of an irrevocable offer ${ }^{44}$ and in case of an offer made by an entrepreneur in the operation of his business, the 'dying' offer rule is considered inapplicable (except where the nature of the transaction or the special circumstances imply the termination of the offer). ${ }^{45}$ When the Spanish Tribunal Supremo ${ }^{46}$ dealt with this question for the first and up to now last time in $1988,{ }^{47}$ it held that an offer, unlike a contract, could not be transferred to the offeror's heirs. ${ }^{48}$ In case of the offeree's death the offer is also considered to lapse. ${ }^{49}$

The recent Spanish proposal for a reform of the law of obligations explicitly abandons the 'dying' offer rule, considering death and incapacitation of either party generally irrelevant for the validity of offers. ${ }^{50}$

\section{d) England}

According to the view expressed in an obiter dictum by Lord Justice Mellish in Dickinson $\mathrm{v}$ Dodds, ${ }^{51}$ the death of the offeror generally terminates the offer. However, this rule, traditionally extended also to the death of the offeree, ${ }^{52}$ is

tos de derecho civil patrimonial, vol I (6 ${ }^{\text {th }}$ ed, Madrid: Civitas, 2007) 349. See for a detailed study of this issue and the independency of the offer: B.M. Quesada, La oferta del contrato (Barcelona: Nereo, 1963) $93 \mathrm{ff}$. See for a more recent critical and comparative discussion of the traditional doctrine in Spain: A.M. Rodríguez Guitián, La muerte del oferente como causa de extinción de la oferta contractual (Madrid: Civitas, 2003).

43 L. Díez-Picazo, Fundamentos de derecho civil patrimonial, vol I ( $2^{\text {nd }}$ ed, Madrid: Civitas, 1983) 207 f; M. del Carmen Gomez Laplaza, in M. Albaladejo and S. Diaz Alabart, Comentarios al Código Civil y Complialciones Forales, vol XVII (Madrid: Ed de Derecho Reunidas, 1993) art 1.262, 91. E. Lalaguna Domínguez, 'Sobre la perfección de los contratos y el código civil', in Homenaje al Profesor Jan Roca Juan (Madrid, 1989) 412 f.

44 Rodríguez Guitián, n 42 above, $136 \mathrm{ff}$.

45 In favour of these exceptions: J. Ribot Igualada, in A. Domínguez Luelmo, Comentarios al Código Civil (Valladolid: Lex nova, 2010) art 1262, 1382.

46 STS 23.3. 1988 (RJ 1988/2422).

47 See on this case: Díez-Picazo, n 42 above, 349 ff; Rodríguez Guitián, n 42 above, $130 \mathrm{ff}$.

48 '[C]onstando el fallecimiento del oferente u ofertante en 14 de septiembre de 1977, no cabe que los efectos de la oferta sean transmisibles a sus causahabientes, a quienes sólo podría vincular (art 1.257 del Código Civil) de haberse perfeccionado el contrato en vida del "decuius", pero no al carecer de existencia en el momento de producirse la apertura de la herencia.'

49 Del Carmen Gomez Laplaza, n 43 above, art 1.262, 93.

50 See $\mathrm{n} 3$ for the text of the proposal.

51 Dickinson v Dodds (1876) 2 ChD 463, 475: 'it is admitted law that, if a man who makes an offer dies, the offer cannot be accepted after he is dead'.

52 See A.T. Carter, Elements of the law of contract (3 ${ }^{\text {rd }}$ ed, London: Sweet \& Maxwell, 1910) 18; E. Jenks, A digest of English civil law, vol 2 (London: Butterworth, 1906) 88, n 193. Reynolds v Atherton (1921) 125 LT 690, 695. M. Firmstone, Cheshire, Fifoot and Furmston's Law of Contract (15 $5^{\text {th }}$ ed, London: Butterworths, 2007) 81. According to Treitel, 
not applied without exceptions. It is considered inapplicable when there is a valid contract not to revoke the offer for a fixed period of time $e^{53}$ and when the offeree did not know about the other party's death and the contract was not one for personal services. ${ }^{54}$ More generally, it is argued, that death should not terminate an offer, except when the 'personal nature' of the future contract justifies the termination..$^{55}$ Supervening personal incapacity is generally subject to the rules for contracts with mentally disordered persons and hence does not by itself terminate an offer. ${ }^{56}$

\section{Legal systems following the 'surviving' offer rule}

Following the solution adopted by the German legislature in 1900, several European codifications contain a rule according to which an offer does not lapse simply because of the death or incapacitation of the offeror. Obviously, this rule, like the 'dying' offer rule, constitutes a prima facie presumption and thus permits exceptions.

\section{a) Germany}

During the preparatory works for the German Civil Code (Bürgerliches Gesetzbuch: $\mathrm{BGB}$ ), the question was raised whether the 'dying' offer rule, sustained by the pandectists, ${ }^{57}$ should be preserved or definitely be abandoned. After a vivid debate, it was decided that an offer should not be considered terminated by the mere fact of death of the offeror. Thus, the previous rule stated in Article 297 for offers of entrepreneurs in the General German Commercial Code of 1869 was extended to all cases of death and incapacitation of the offeror. Notwithstanding the prevailing contrary opinion, this rule was not entirely new by then, since the Prussian Code (I, 5, $\mathbb{\$} 106-108$ Allgemeines

however, an offer can be considered to be made to the deceased or his executors if it is not referred to a contract of personal nature. G.H. Treitel, in Chitty on Contracts, vol 1 (30th ed, London: Sweet \& Maxwell, 2008) 2-101.

53 Treitel, n 52 above, 2-099.

54 Bradbury v Morgan (1862) 1 H \& C 249.

55 Treitel, n 52 above, 2-099; G.H. Treitel, The law of contract (12 ${ }^{\text {th }}$ ed, London: Sweet \& Maxwell, 2007) 47. See also Firmstone, n 52 above, 80: 'The truth would seem to be that the effect of death varies according to the nature of the particular contract. If, as in the case of guarantee, the offer is of a promise which is independent of the offeror's personality and which can be satisfied out of his estate, death does not, until notified, prevent acceptance. If, as in the case of agency or in an offer to write a book or to perform at a concert, some element personal to the offeror is involved, his death automatically terminates the negotiations.'

56 Treitel, n 52 above, 2-102.

57 B. Windscheid, Lehrbuch des Pandektenrechts, vol 2 (3 ${ }^{\text {rd }}$ ed, Düsseldorf: Buddeus, 1870) 163. 
Landrecht) as well as the Saxon Code ( $\$ 818$ Sächsisches Gesetzbuch) had already introduced a rule against a general termination of offers in case of death, allowing the offer to lapse only when it was tied to personal relations. The basic argument for the decision ${ }^{58}$ to abandon the 'dying' offer rule was that offers are not so much the result of strictly personal decisions, but are usually made because of economic needs or pecuniary interests. These economic reasons would continue to exist even after the offeror died or was incapacitated and the estate was transferred to others. ${ }^{59}$ An exception to this rule was considered to be justified only in cases in which the offer reveals a contrary intention by the offeror. As far as the death of the offeree is concerned, the first draft of the BGB contained a rule that comprised both the death of the offeror and the death of the offeree. During the discussion, however, this provision ( $\$ 89$ of the first draft) was modified and restricted to the death of the offeror, arguing that it would be highly problematic (without further explanation) if offers were generally considered to be addressed not only to the offeree but also to his or her heirs. ${ }^{60}$

The rules finally adopted on this issue are contained in $\$ 130(2)$ and $\$ 153$ BGB. According to $\$ 130(2) \mathrm{BGB}$, the effectiveness of a declaration of intention is not affected by the supervening death or incapacitation of the author of the declaration. This rule applies to both the offer and the acceptance (empfangsbedürftige Willenserklärungen). $\$ 153 \mathrm{BGB}$ repeats this principle with regard to death or incapacitation of the offeror, stating that the offer is not terminated by the offeror's death or incapacitation, except in cases where the offeror's contrary intention can be presumed. The contrary intention has to be derived from the objective meaning of the offer taking into account the circumstances which the offeree could have known. ${ }^{61}$

58 The fact that offers are generally binding under German law ( $\$ 145 \mathrm{BGB})$ was not relevant for this decision. But see on the question whether the revocability or irrevocability of an offer has any consequences on the rule applied in case of the offeror's death: IV, 2, d).

59 'Der den erwähnten Gesetzgebungen zu Grunde liegende Gesichtspunkt, dass Vertragsanträge regelmäßig aus einem wirthschaftlichen Bedürfnise oder wenigstens aus einem Geldinteresse hervorgehen, und dass dieses Bedürfnis bzw. Interesse der Regel nach mit dem Vermögen bestehen bleibt, wenn solches auch mit dem Tode des bisherigen Inhabers in andere Hände übergeht, ist vollberechtigt.' Motive zu dem Entwurfe eines bürgerlichen Gesetzbuches für das Deutsche Reich, vol 1 (Berlin/Leipzig: Guttentag, 1888) 176.

60 'Was den Tod und den Eintritt der Geschäftsunfähigkeit des Angebotsempfängers anlangt, so entschied man sich insoweit für die Streichung der Bestimmung des $\$ 89$, weil man dieselbe für bedenklich hielt. Bezüglich des Todes müsste die Vorschrift, wenn sie beibehalten werden sollte, dahin aufgefasst werden, dass der Antrag als an die Erben des Adressaten gerichtet anzusehen sei, ein Satz, welcher Bedenken unterliege.' A. Achilles, P. Spahn and A. Gebhard, Protokolle der Kommission für die zweite Lesung des Entwurfs des Bürgerlichen Gesetzbuchs, vol 1 (Berlin: Guttentag, 1897) $86 \mathrm{f}$.

61 R. Bork, in Standinger, Kommentar zum BGB (Berlin: Sellier/de Gruyter, 2010) \$153, Rn. 5: 'Vielmehr ergibt sich unmittelbar aus $\$ 153$, daß ein entgegenstehender Wille im 
If, on the other hand, the offeree dies before he receives or accepts the offer, there is no presumption that the offer would continue to be effective. In fact, in these cases the offer has to be interpreted according to its objective meaning in order to determine whether the offer was exclusively directed to the offeree or also to his or her heirs.

\section{b) Austria}

In its original version, the Austrian code (Allgemeines Bürgerliches Gesetzbuch: ABGB) of 1811 explicitly stated that a pending offer could not be transferred to the offeror's or offeree's heirs. ${ }^{62}$ With the third partial amendment to the Austrian Civil Code in $1916^{63}, \mathbb{} 912 \mathrm{ABGB}$ was abrogated and $\$ 862$ ABGB was modified. Since then offers are generally considered to remain unaffected by death or incapacitation of either party, unless the offeror's contrary intention appears from the circumstances. ${ }^{64}$ Hence, if the circumstances allow the conclusion that the offeror did not intend his offer to survive either party's death, the presumption contained in $\$ 862$ ABGB does not apply and the offer lapses. The Austrian solution differs from the German $\$ 153$ BGB only with regard to the offeree, since unlike in German law the (rebuttable) presumption that the offer is not terminated by death or incapacitation applies even in those cases in which the offeree dies or is incapacitated before the conclusion of the contract.

\section{c) Portugal and the Netherlands}

The Portuguese Civil Code from 1966 follows the German Civil code with two provisions modelled after $\$ 130 \mathrm{BGB}$ and $\$ 153 \mathrm{BGB}$. According to Article 226(1) ${ }^{65}$ Código Civil, supervening death or incapacitation does not affect the validity of a declaration of intention, unless the contrary emerges from the

Wege der Auslegung festgestellt werden kann. Für diese Auslegung müssen die allgemeinen Regeln gelten, dh es ist unter Berücksichtigung der für den Empfänger erkennbaren Umstände der objektive Erklärungswert des Angebotes festzustellen.'

62 \918 ABGB (version of 1811): '(...) Ein noch nicht angenommenes Versprechen geht, wenn auch nur ein Theil während der Überlegungsfrist stirbt, auf die Erben nicht über.'

63 So called 'III. Teilnovelle', Kaiserliche Verordnung v 19.3. 1916, RGBl 1916, Nr. 69, 201. For a brief comment on the amendment regarding this issue, see W. Schlesinger, in $\mathrm{H}$. Klang, Kommentar zum Allgemeinen Bürgerlichen Gesetzbuch, II/2 (Wien: Verlag der Österreichischen Staatsdruckerei, 1934) \$862, $64 \mathrm{f}$.

$64 \int 862$ ABGB: 'Er [der Antrag] erlischt auch nicht, wenn ein Teil während der Annahmefrist stirbt oder handlungsunfähig wird, sofern nicht ein anderer Wille des Antragstellers aus den Umständen hervorgeht.'

65 Art 226(1) CC: 'A morte ou incapacidade do declarante, posterior à emissão da declaração, não prejudica a eficácia desta, salvo se o contrário resultar da própria declaração.' 
declaration itself. Article $231^{66}$ Código Civil states that the offeror's death or incapacitation does not terminate the offer, unless there are reasons to presume that the offeror had a contrary intention. Unlike the German Code, Article 231 Código Civil states explicitly that death or incapacitation of the offeree terminates the offer. Hence, if the offeree dies, the offeror needs to make a new offer to the offeree's heirs in case he wishes to contract with them. ${ }^{67}$

According to Article 6:222 ${ }^{68}$ of the Nieuw Burgerlijk Wetboek an offer is generally not affected by death or incapacitation of one of the parties. According to Article 6:217, however, this rule only applies if the offer, another juridical act or usage do not require otherwise. So if, on the basis of a reasonable interpretation, the offer is considered to pertain to the personal sphere of the offeror, it lapses after either party's death. ${ }^{69}$

\section{Evaluation of the reasons for and against the 'dying' offer rule}

\section{The historical reason. The 'meeting of the minds' requirement}

As has been laid out above, the development of the 'dying' offer rule can be traced back to the commentators of the $14^{\text {th }}$ century and was a result of the then dominant theory according to which a contract could only be concluded by simultaneous declarations of intention. When the offeror sent his offer by mail he was considered to be talking to the offeree in the very moment of acceptance. Supervening death or mental illness rendered this fiction of simultaneous declarations of intention impossible. Hence, it was a logical consequence for the medieval commentators to consider a pending offer lapsed as soon as the offeror was physically (death) or legally (mental illness) impeded from declaring his intention. Moreover, a transfer of the offer to the offeror's heirs was also not conceivable, since until the very moment of acceptance there was no final declaration of intention. Prior to that moment, in fact, the offeror had not yet spoken through the letter.

66 Art 231 CC: '1. Não obsta à conclusão do contrato a morte ou incapacidade do proponente, excepto se houver fundamento para presumir que outra teria sido a sua vontade. 2. A morte ou incapacidade do destinatário determina a ineficácia da proposta.'

67 'Já a morte ou incapacidade superveniente do destinatário da proposta determina a sua caducidade (artigo 231, n 2). Se o proponente quiser, sempre poderá emitir nova proposta, de igual teor dirigida aos herdeiros do destinatário; se não estiver interessado em manter a proposta, bastará nada fazer.' P. Pais de Vasconcelos, Teoria Geral do Direito Civil (6 th $^{\text {th }}$ ed, Lisboa, 2010) 476.

68 Art 6:222 NWB: 'Een aanbod vervalt niet door de dood of het verlies van handelingsbekwaamheid van een der partijen, noch doordat een der partijen de bevoegdheid tot het sluiten van de overeenkomst verliest als gevolg van een bewind.'

69 W.L. Valk, 'Art. 6:222', in J.H. Nieuwenhuis, C.J.J.M. Stolker, W.L. Valk and M.H. Wissnik, Vermogensrecht Tekst E Commentaar (5 ${ }^{\text {th }}$ ed, Deventer: Kluwer, 2009) 859. 
The requirement of simultaneous declarations of intention was a corollary of the will theory on which consensual contracts in Roman law were founded. ${ }^{70}$ According to this theory the conclusion of a contract required a coincidence of the parties' subjective intentions (meeting of the minds) and this, of course, could only be guaranteed if the parties expressed their intentions at the same time. With regard to an offer sent by a letter it was always unclear whether the offeror still wanted what he had written. Where he had revoked his offer before the offer was accepted, a simultaneous consent was no longer possible ${ }^{71}$ ('ubi enim scribentem penituit, tunc scriptura nibil operatur, nec potest scribentem obligare: quia scriptura nudum praestat ministerium [...] et ideo ubi ponitet scribentem, deficit illius consensus; et quod inde sequitur non potest effectum fortiri ${ }^{72}$ ).

According to modern formation of contract theory, ${ }^{73}$ however, an offer is considered to be complete once it is declared in a perceptible way (manifestation of the intention) either orally, by writing or by conclusive conduct. Hence, the letter containing the offer is not just an instrument that allows the offeror to 'talk' to the offeree in his absence, but is a way to declare one's intention conclusively. So once the letter is sent, the addressee can rely on the objective meaning of the declaration (words, circumstances), until he receives notice of a different intention. Supervening subjective changes in the offeror's mind which remain unexpressed can therefore not preclude the conclusion of the contract. This modern view is confirmed both by the Principles of European Contract Law and the DCFR. According to Article 2:102 PECL 'the intention of a party to be legally bound by contract is to be determined from the party's statements or conduct as they were reasonably understood by the other party. ${ }^{74}$ It is thus the external manifestation of intention as perceived by a reasonable offeree which has to be taken into consideration (reliance theory). Hence, if somebody makes an offer to sell his car and after sending the offer regrets having offered it at the declared price, his or her subjective change of

70 M. Kaser, Das römische Privatrecht I (Munich: C H Beck: 1955) 206 f. See R. Zimmermann, The Law of Obligations (Oxford: Oxford University Press, 1996) 564: '[In classical law] no formal act was needed fort he conclusion of consensual contracts; they were based merely on the consent of the parties, and they formed the nucleus around which the modern law of contract was to develop. Admittedly, consensus was not a wellanalysed technical term but it did mean, first and foremost, what the English term 'consent' is ususally also taken to convey: a meeting of the minds, the concurrence of two or more wills, and hence something essentially subjecitve.'

71 On this problem see J. Gordley, The Philosophical Origins of Modern Contract Doctrine (Oxford: Clarendon Press, 1991) $46 \mathrm{ff}$.

72 Giovanni Pietro Sordi, n 14 above, n 136, 47.

73 See on consent and its meaning in modern contract law Zimmermann, $\mathrm{n} 70$ above, $559 \mathrm{ff}$.

74 II-4:102 DCFR: 'The intention of a party to enter into a binding legal relationship or bring about some other legal effect is to be determined from the party's statements or conduct as they were reasonably understood by the other party.' 
mind won't affect the conclusion of the contract, unless the offeror revoked the offer if and as long as this was still possible (Articles 2:202 PECL, II-4:102 DCFR).

\section{Modern reasons for and against the 'dying' offer rule}

As the historical reasons could no longer justify the 'dying' offer rule, modern legal systems had to adapt the rule to the reliance theory in contract formation. This required limiting its area of application. In fact, none of the systems illustrated above actually imposes the termination of an offer without exceptions. Similarly, those systems which generally consider an offer to survive the death of the offeror do not impose the survival of the offer in every instance. Hence, it seems accurate to state that in modern legal systems where consent is established by the meeting of two corresponding declarations of intention the 'dying' offer rule has been largely transformed into a prima facie rule. ${ }^{75}$

\section{a) The fundamental consideration: is contracting strictly personal?}

But on the basis of which fundamental consideration can the termination or the survival of offers be presumed? When during the preparatory works for the German Civil Code the drafters decided to abandon the pandectists' 'dying' offer rule, the main argument was that in modern times contractual relationships primarily serve an economic need or a pecuniary interest and offers should thus survive just like the offeror's assets which they ultimately serve. ${ }^{76}$ Even though this generalization may not be generally accepted, it seems indeed that the crucial point lies here. In legal systems in which contracting is considered to be mainly determined by strictly personal reasons, the 'dying' offer rule will most likely be chosen as the standard rule. On the other hand, in systems where the primary purpose of contracting is considered to be economic and an offer is mainly conceived as a way 'to make profit', offers will generally not lapse with the death of the offeror. ${ }^{77}$

75 Luis Diéz-Picazo points out that the developments in the most recent literature show that there are no dogmatic reasons which can be advanced for a certain solution. The rules contained in modern codifications all seem to be rules of interpretation and presumption. See Díez-Picazo, n 42 above, $350 \mathrm{f}$.

76 Motive zu dem Entwurfe eines bürgerlichen Gesetzbuches für das Deutsche Reich, n 59 above, 176.

77 It is therefore very surprising and can only be explained historically that in the United States, where contracting is undoubtedly conceived as mainly economic, courts still follow $\ 48$ Restatement (Second) of Contracts according to which: 'An offeree's power of acceptance is terminated when the offeree or offeror dies or is deprived of legal capacity to enter into the proposed contract.' Comment a) then considers this rule to be a 'relic of the obsolete view that a contract requires a 'meeting of minds,' and it is out of harmony with the modern doctrine that a manifestation of assent is effective without 
The exceptions to both the 'dying' offer rule and the 'surviving' offer rule confirm this fundamental consideration. When in Italian law the 'dying' offer rule is generally not applied to offers made by an entrepreneur (Article 1330 Codice Civile) ${ }^{78}$ this exception is justified by the fact that personal factors are generally considered to be of minor relevance in professional relationships. ${ }^{79}$ However, even in professional relationships the offer lapses if personal considerations prevailed in the formulation of the offer, like, eg, if the offeror is a small entrepreneur or the nature of the transaction or the circumstances justify its termination. Similarly, it has been argued in English law that the general rule should be that death of either party should never terminate an offer, 'unless the offer is one to enter into a contract that because of its personal nature would be determined by the death of either party'. ${ }^{80}$

In systems in which offers generally remain unaffected by the death of the offeror, offers will be terminated if the personality of one of the parties turns out to be essential for the conclusion of the contract. In German law, for example, an offer lapses if this is the (objectively) presumed intention of the offeror ( $\$ 153$ BGB). The same applies in Austria where the offeror's intention to terminate the offer has to be derived from the circumstances ( $\$ 862 \mathrm{ABGB})$. Equivalent exceptions referring to the offeror's (objective) intention, to the nature of the transaction or the circumstances also apply in Portugal, the Netherlands as well as in the Spanish and Czech drafts.

\section{b) Protection of the parties from unplanned contracts}

In Italy, where in light of specific textual references in the code the general validity of the 'dying' offer rule is least controversial, the two main arguments recently advanced in favour of the rule ${ }^{81}$ are referred to the need of protection by the parties. On the one hand, the 'dying' offer rule would protect the offeror's heirs, who would otherwise be dragged into an unplanned and maybe

regard to actual mental assent.' On the 'dying' offer rule in the US with ample references see: Ricks, $\mathrm{n} 2$ above.

78 The same rule is adopted in Spain and was in place in commercial law in Germany before the 'dying' offer rule was generally abandoned ( $\$ 297$ ADHGB of 1861).

79 Relazione al codice civile, 608 f; G.C.M. Rivolta, 'Proposte e accettazioni contrattuali nell'esercizio dell'impresa' Rivista di diritto civile 1991, I, 1 ff; Scognamiglio, n 35 above, 138 f: 'Si vuol dire che l'impresa, come attività economica, organizzata e professionale, assume una sua innegabile dimensione oggettiva, che ne determina la sopravvivenza (o propensione a sopravvivere) al di là, almeno per gli effetti immediati delle contingenti vicende della persona del titolare.' See also Roppo, n 35 above, 149: 'il distacco del contratto dalla sfera personale del dichiarante'. For this exception in Spanish law: Díez-Picazo, n 42 above, 351; Ribot Igualada, n 45 above, art 1262, 1382.

80 Treitel, $\mathrm{n} 52$ above, 2-099.

81 Roppo, n 35 above, $146 \mathrm{f}$. 
also undesired contract..$^{82}$ On the other hand, the termination of offers would also protect the offeree from a contract that he or she might have wanted to conclude only with the offeror and not with his or her heirs.

These reasons are not convincing. Making the need for protection dependent on the mere contingency of death seems arbitrary and cannot reasonably explain the 'dying' offer rule. Why would the offeror's heirs and the offeree need protection from undesired contracts only in cases in which the contract is not concluded before the death of the offeror? In fact, had the accepted offer been received by the offeror only seconds before his death, the contract would be concluded and thus be transferred to the heirs, as long as it was not a contract intuitu personae. Thus it seems clear that the need for protection does not depend on the contingency of death, but ultimately relies on the characteristics of the offer and the importance of the parties' personality in its formulation. ${ }^{83}$

Overall, the 'dying' offer rule is neither necessary nor sufficient nor adequate for the protection of either party. It is not necessary because (at least) the same protection can be achieved by the opposite rule according to which offers generally survive, except where personal factors played a major role. It is not sufficient, because if the contract is concluded only one second before the death of the offeror, the 'dying' offer rule does no longer protect the offeror's heirs from undesired surprises. Finally, the 'dying' offer rule in its absoluteness is also inadequate because it generally terminates all offers and not only those which - because of the prominence of the parties' personality really need to be terminated.

\section{c) Legal certainty and protection of the offeree's reliance}

It has been argued against the 'dying' offer rule that death and other events regarding the offeror should not affect the validity of the offer as long as they remain unknown to the offeree. This would be necessary to protect the reliance of the offeree ${ }^{84}$ However, this argument is only valid as far as it coincides

82 This seems to be the argument that was adopted also by the Projet de la chancellerie in France. See $n 32$.

83 In this sense also A. Bénabent, Droit civil Les obligations (9th ed, Paris: Montchrestien, 2003) 47: 'La solution logique serait de distinguer selon que la personalité du contractant est déterminante ou non: si oui (contrat intuitu personae) le décès rend l'offre caduque tout comme il rendra le contrat lui-même caduc s'il survient après sa conclusion mais avant son exécution; sinon le contrat peut parfaitement être conclu avec les successeurs du défunt (héritiers pour une personne physique, 'repreneurs' pour une entreprise) et la caducation ne paraît guère justifiée.' Kötz and Flessner, n 9 above, 25: 'Everyone agrees, however, that these rules are residual and that the answer really depends on the particular circumstances of the case, especially on whether the personal qualities of the party are relevant to the contract in question.'

84 This argument is mentioned by del Carmen Gomez Laplaza, n 43 above, art 1.262, 89. 
with the argument according to which an offer will be terminated only in those cases in which the parties' personality has played a major role in the formulation of the offer. This is to say that the offeree's reliance on the offer should be protected only insofar as a reasonable person would have trusted in the continuing validity of the offer even after the offeror's death. If A offers his car to his good friend B at a special price, B's reliance that the offer will be valid even after A's death seems not worthy of protection because from the circumstances he must know that the special price is due to his friendship to A. The offer will therefore lapse without disturbing the certainty of legal traffic.

\section{d) Revocability of offers and the termination of offers}

Does the 'dying' offer rule follow from the free revocability of offers? A comparative analysis of the legal systems might lead to the conclusion that the revocability or irrevocability of offers determines the rule on whether offers are generally considered to lapse or not. One could argue that in systems in which offers are generally binding (like in Germany ${ }^{85}$ and Austria ${ }^{86}$ ) the rule to be adopted should be the 'surviving' offer rule. This conclusion appears to receive further confirmation by the exceptions for irrevocable offers in 'dying' offer rule systems. In Italy, for example, Article 1329(2) Codice civile explicitly states that irrevocable offers do generally not lapse with the death or incapacitation of the offeror. ${ }^{87}$ The same applies to irrevocable offers in French, Spanish and English law. ${ }^{88}$ However, there is no interdependency between the irrevocability and the 'survival' of an offer, ${ }^{89}$ like there is no interdependency between revocability and the 'dying' offer rule. ${ }^{90} \mathrm{In}$ fact, even irrevocable offers lapse with the death of either party if the personal identity of one or both parties was essential for the future contract. With regard to revocable offers, it has been argued that the difficulty for the heirs to know about pending offers would render them factually irrevocable if they were not subject to the 'dying' offer rule. This argument, however, is not convincing, because regardless of whether the heirs face factual difficulties in revoking an offer, the offeree relies

$85 \int 145$ BGB: 'Wer einem anderen die Schließung eines Vertrags anträgt, ist an den Antrag gebunden, es sei denn, dass er die Gebundenheit ausgeschlossen hat.'

$86 \rrbracket 862$ ABGB: 'Vor Ablauf der Annahmefrist kann der Antrag nicht zurückgenommen werden.'

87 The same exception for irrevocable offers can be found in art 1105-4 of the French avantprojet Catala (n 1 above).

88 See above, text and $\mathrm{n} 45$ and 53.

89 Such interdependency, however, can be explained from a historical perspective, since only in case of an irrevocable offer the offeror expressed his intention conclusively so that supervening events before the acceptance became irrelevant.

90 See for Italy Sacco, n 35 above, 217 (contra: Cass civ 6. 5. 1965, Giust civ 1966, I, 542) and for Spain del Carmen Gomez Laplaza, n 43 above, art 1.262, 96. For France: Chabaan, n 18 above, 263. 
on the validity of the offer as long as it is not revoked. This reliance should not be disappointed unless the offer appears to be based on objectively cognizable personal considerations that require the contract to be concluded with the offeror himself (eg because it was an offer to buy or sell goods or services that only the offeror could make or give or it was an offer that because of the special conditions only the offeror himself would have made to the offeree).

\section{e) Inheritance law and the 'dying' offer rule}

Do offers terminate with the death of the offeror because the law of succession bars their transfer? Under the Italian Codice Civile of $1865^{91}$ as well as in Spanish law, ${ }^{92}$ it was argued that the 'dying' offer rule can be derived from the principle that only rights and obligations are transferred to the heirs. According to Article 659 Código Civil, the estate comprises all personal and real property as well as rights and obligations of a person which are not extinguished by death. Hence, the Spanish 'dying' offer rule was considered to follow from Article 659 Código Civil. ${ }^{93}$ However, there is general agreement in Spain that Article 659 Código Civil simply describes the universal scope of the law of succession, without limiting its content. ${ }^{94}$ Moreover, if it were really the case that pending offers could not be transferred to the heirs, this would necessarily hold even for those offers which the offeror explicitly wished to be transferred. ${ }^{95}$ This conclusion can obviously not be accepted because the rules regarding the effects of the offeror's death are generally considered to be dispositive law. ${ }^{96}$ Finally, it has to be considered, that an offer - even though it is neither a right nor an obligation - creates both in the offeror and in the offeree a legally and economically relevant position ${ }^{97}$ which in the

91 Scaduto, n 34 above, $124 \mathrm{f}$.

92 Del Carmen Gomez Laplaza, n 43 above, art 1.262, $91 \mathrm{ff}$.

93 STS 23.3.1988 (RJ 1988/2422). In France this opinion is sustained by Chabaan, $n 18$ above, 264: 'Qu'elle soit ou non assortie d'un délai, l'offre est un acte juridique unilateral intransmissible à cause de mort.'

94 F. de Asís Sancho Rebullida, in Ministerio de Justicia, Comentario al Código Civil, vol I, Art. 659, 1660: 'Este art. 659 no tiene por objeto fijar el contenido de la herencia, sino señalar el ámbito exhaustivo del fenómeno sucesorio’. See also Rodríguez Guitián, n 42 above, $66 \mathrm{ff}$.

95 See in this sense, however, the Italian decision Cass civ 6. 5. 1965, n 827, Giust civ 1965, I, 542. For the irrelevance of an express declaration with a different reasoning Roppo, n 35 above, 150.

96 Del Carmen Gomez Laplaza, n 43 above, art1.262, 95 according to whom in order to find out whether an offer survives the intention of the offeror has to be taken into account. In Italy: Sacco, n 35 above, 217. From a comparative perspective: Kötz and Flessner, $\mathrm{n} 9$ above, 24 ('these rules are residual').

97 'Sin duda la oferta es una posición patrimonial representativa de un valor.' Rodríguez Guitián, n 42 above, 70. 
absence of a special provision that prohibits its transfer ${ }^{98}$ has to be considered part of a person's assets and is thus passed on to the heirs.

Inheritance law obviously does not bar the transfer of an offer to the offeror's or offeree's heirs. The question, in fact, is not one about the general transferability of offers by death, but one about the conditions of transferability which have to be established within contract law.

\section{A rule for a future European contract law}

As has been pointed out in the introduction, both the PECL and the DCFR do not contain any rule on the effects of death or incapacitation of the offeror or offeree on pending offers. In this respect both projects might have followed the CISG which similarly decided against a rule on this issue because of its asserted 'minimal importance' in international trade. ${ }^{99}$

\section{Why a rule in a future European contract law?}

Hence the question arises whether a future European contract law should contain a rule on the issue.

The diverging interpretations of the silence in the CISG seem telling. While some argued that the question constitutes an external gap and thus needs to be solved on the basis of national law, ${ }^{100}$ others considered the gap to be internal in the sense that offers generally do not lapse with the death or incapacitation of either party. ${ }^{101}$ These diverging ways of understanding the silence in the CISG show that a special rule is required in order to prevent doubts and to ensure certainty in a future European contract law.

Moreover, it has to be considered that bringing together different national legal traditions in one set of rules is a task which requires enacting rules that reflect these traditions. The fact that all the legal systems considered here have

98 Rodríguez Guitián, 42 above, 70.

99 Report of the Working Group on the International Sale of Goods on the Work of its ninth session (Geneva, 19-30 September 1977, Doc A/CN.9/142), Yearbook of the United Nations Commission on International Trade Law vol IX, 1978, 81, n 281.

100 See eg P. Schlechtriem, in I. Schwenzer and P. Schlechtriem, Commentary on the UN Convention on the International Sale of Goods (CISG) (3 ${ }^{\text {rd }}$ ed, Munich: C H Beck, 2010) Art. 15, n 8; P. Mankowski, in F. Ferrari, E. Kieninger and P. Mankowski et al, Internationales Vertragsrecht (Munich: C H Beck, 2007) Art. 15, n $19 \mathrm{ff}$.

101 Eörsi, in C.M. Bianca and M.J. Bonell, Commentary on the international sales law (Milan: Giuffré, 1987) Art.16, 1.2.1; U. Magnus, in Staudinger, Kommentar zum $B G B$ (Berlin: Sellier/de Gruyter, 2005) Art. 15, CISG, n 13 ff. 
developed special rules on this question appears to constitute a sufficient reason for introducing a corresponding rule in a future European contract law.

In the light of these considerations, a presumed lack of practical relevance derived from the small number of court decisions on the issue doesn't seem to constitute a convincing reason against a special rule. On the one hand, rules also serve the function of preventing litigation. Therefore, their practical importance cannot be assessed by simply looking at the number of court decisions on the issue. On the other hand, there is a large and increasing field of application for such a rule comprising in particular irrevocable offers and offers sent by mail (either traditionally or electronically).

\section{Scope of application}

Granted that there is a need for a rule on the issue in a future European contract law, the question of its material scope needs to be addressed. Should both the death of the offeror and the death of the offeree be taken into account? What about incapacitation?

It seems to be preferable not to distinguish between the death of the offeror and the death of the offeree since they raise similar problems. In both cases, in fact, the question arises whether the offer was (actively or passively) sufficiently impersonal to survive either party's death. This is the solution adopted in Austrian and Dutch law (as well as in the Spanish and Czech draft) where the presumption of survival of the offer holds for the death of either party. Conversely, in French law as well as in Portuguese law an offer generally lapses with the offeree's death (Article 231 Código Civil), whereas in German and English law an offer is only presumed to lapse with the offeree's death as long as the offer cannot be interpreted in the sense that it was also directed to the offeree's heirs.

The rules applied with regard to the death of a physical person should analogously be applied to the extinction of a corporation (eg by merger). ${ }^{102}$

Incapacitation should not be part of the rule. There appears to be no reason at all to equate incapacitation with death. The fact that both situations are considered together and remain together even in most recent reform drafts (eg in France, Spain, Czech Republic) is a relic of the historical origins of the rule. ${ }^{103}$

102 In this sense: Rivolta, n 79 above, 18; Bénabent, $\mathrm{n} 83$ above, 47; in Germany for the applicability of $₫ 153$ BGB in case of a merger: OLG Düsseldorf 18.10.2006, Zeitschrift für deutsches und internationals Bau- und Vergaberecht 2007, 400; S. Mutter and S. Stehle, 'Vertragsangebote in der Verschmelzung' GmbH-Rundschan 2003, 290 291; R.-Chr. Stratz, in J. Schmitt, R. Hörtnagl and R.-Chr. Stratz, Umwandlungsgesetz, Umwandlungsstenergesetz ( $5^{\text {th }}$ ed, Munich: C H Beck, 2009) $\$ 20$ UmwG, n 35 .

103 See W. Flume, Allgemeiner Teil des Bürgerlichen Rechts - Das Rechtsgeschäft (3rd ed, 
According to the medieval commentators a person that after sending the offer became unsound of mind, just like a dead person, could no longer speak through the letter. This impeded the contract from being concluded. In the light of the modern basis of the rule, death and the declaration of legal incompetence are fundamentally different. In particular, the party's personality is not extinguished by the declaration of incompetence. Incapacitation therefore raises questions that are better solved within the general rules for the protection of people with mental disabilities. ${ }^{104}$ The mere contingency that the declaration of incompetence occurs between the offer and the conclusion of the contract cannot by itself be decisive for the termination of an offer.

Incapacitation regularly follows also from the declaration of bankruptcy. To what extent bankruptcy leads to incompetence and whether offers should remain valid or terminate with the declaration of bankruptcy are questions that are best solved by bankruptcy law. Generally, however, the mere fact of a supervening bankruptcy should not make an offer lapse, since the resulting contract could very well be advantageous for the debtor's assets.

\section{Which criteria for a common rule?}

With regard to the specific content of a common European rule, two basic criteria can be inferred from the above analysis.

From the defences of the 'dying' offer rule advanced in different legal systems it appears that the general rule regarding the effects of death on an offer is decided on the basis of a presumption of how 'personal' contracting is commonly perceived. Assuming that in modern days contracts are prevalently concluded on the basis of impersonal, economic interests, ${ }^{105}$ the general presumption should be that the death of either party does not affect the validity of an offer. Who rejects this heuristic assumption might still agree that death by itself is a mere contingency that as such is inconclusive as to its effects on an

Berlin: Springer, 1979) 648: 'Wenn in $\$ 153$ neben dem Tod die Geschäftsunfähigkeit des Offerenten erwähnt wird, ist dies durch die gemeinrechtliche Lehre bestimmt, welche beide Fälle gleichstellte.'

104 See for English law Treitel, n 52 above, 2-102; de iure condendo for Italian law Scognamiglio, n 35 above, 137; A. Ravazzoni, La formazione del contratto I (Milan: Giuffré, 1966) $142 \mathrm{ff}$.

105 Though surely not uncontroversial, this assumption seems to better reflect the modern economy in which the parties of a contract do usually not know each other and even care little about the other party's personality. It is also in line with the general rule according to which contracts are transferred by death. As will be seen immediately in the text, this presumption does not deny that there are many instances even today in which personal characteristics of either party are decisive for the conclusion of a contract (eg guarantee contracts; certain service contracts where the service needs to be performed by one specific person - the classic example of the opera singer). 
offer. Both the draft for a new Spanish law of obligations and the draft for a new Czech civil code consider death to be generally inconclusive as to the effects of an offer, following in this respect the German, Austrian, Portuguese and Dutch rules. Only the French drafts for a new law of obligations (avantprojet Catala, projet de la Chancellerie, and the projet Terré) continue to follow the traditional 'dying' offer rule.

The second criterion can also be derived from the above analysis. There appears to be an overarching consensus in European legal systems that offers regardless of whether the 'dying' offer rule is applied or not - should not survive the death of either party if personal considerations played a significant role with regard to the formulation of the offer. This is the case if the circumstances reveal that the offer was meant to be bound to the personality of the offeror and/or the offeree. Hence the common core on the issue seems to be that, in cases in which the personal identity of one or both parties turns out to have been essential for the future contract, the offer lapses with the death of either party.

Whether the personal identity of the parties was actually essential, should not be inferred from an interpretation of the hypothetical subjective intention of the parties, ${ }^{106}$ but from an interpretation of the objective meaning of the parties' 'statements or conduct as they were reasonably understood by the other party'. ${ }^{107}$ In accordance with the declaration theory in contract formation, subjective intention is immaterial as long as it remains unexpressed volition. Thus the offer lapses only in cases in which a reasonable offeree was able to understand from the other party's statements or conduct (eg the words or the terms of the offer, or nonverbal understandings due to the circumstances) that the contract would not be concluded if the offeror died. Consequently, there is also no reason to grant damages for expenses anticipated by an offeree who relied on the validity of a lapsed offer, ${ }^{108}$ because the offeree knew or in any

106 See Flume, n 103 above, $646 \mathrm{f}$.

107 Art 2:102 PECL; art II- 4:102 DCFR.

108 The protection of the offeree's reliance interest was already considered by Baldo degli Ubaldi, n 13 above, D 17.1.1: 'Puto tamen quod recipiens nuntium vel epistola, si aliquas impensas fecisset, vel damna habuisset, propter nuntium vel epistulam ante certiorationem vel scientiam de poenitentia et revocatione mittentis ad expensas et damna possit agere'. This rule was adopted by Pothier, n 20 above, vol 1, 31 f; in Germany, it is still debated whether there is any reason to grant damages in these cases and the answer depends on whether the exceptional cases of termination of an offer are derived from the hypothetical (subjective) intention of the offeror or from an objective intention: see Bork, $\mathrm{n} 61$ above, $\mathbb{\$} 153, \mathrm{Rn} .8$; against damages in these cases in Italy under the Codice civile of 1865: Giorgi, $n 34$ above, 298. In the Italian Code of 1942, the offeree's reliance is protected only in cases in which a revocable offer is revoked before the contract is concluded and the offeree has already started performance in good faith (art 1328). 
case could have known that the other party's death would prevent the contract from being concluded and he would thus bear the risk for this event. ${ }^{109}$

The nature of the transaction (eg contract of agency) cannot by itself be conclusive as to the question whether an offer lapses with death or not. ${ }^{110}$ While it can obviously be an important factor to determine the 'personal nature' of the contract, it is necessary to show that - according to the statements or conduct as they were reasonably understood by the other party - personal considerations were actually essential.

\section{A rule proposal}

The above analysis allows the formulation of the following rule for a future European contract law:

\section{'Death and incapacity}

(1) An offer or acceptance remains unaffected by the supervening death or incapacity of either party.

(2) In case of death, the offer or acceptance lapses only if such intention can be inferred from the statements or conduct as they were reasonably understood by the other party.'

Paragraph 1 states the general presumption according to which the mere contingency of death or incapacity cannot affect a pending offer or acceptance. The reference to both the offer and the acceptance (which can be found, for example, in Article 1330 Italian Civil Code or in the Spanish draft for a reform of the law of obligations) seems advisable, since it might well occur that the other party's identity was essential only for the offeree but not so for the offeror. So, for example, if a famous architect who works together with his son offers to design a building at a certain price, there is no doubt that the architect's personality can and will usually be essential for the offeree, whereas the offeree's personal identity is usually less important for the architect. So if the architect dies after the acceptance but before the conclusion of the contract, the acceptance (and not the offer) is terminated before the contract can be concluded with the architect's son and heir. Similarly, if A grants a loan by accepting B's offer to pay him an interest rate below the one practised by

109 See Flume, n 103 above, 647.

110 See, however, Rodríguez Guitián, n 42 above, 77 who establishes two criteria: the nature of the transaction (contracts intuitu personae) and the intention of the offeror. Both criteria (with the exceptions that Rodriguez Guitian allows) can be reduced to the criterion indicated in the text above. It is neither the nature of the transaction itself nor the sole intention of the offeror, but the objective meaning of the parties' 'statements or conduct as they were reasonably understood by the other party' that determines whether the offer should lapse or not. 
banks, then the acceptance of $A$ is linked to the personality of $B$, while for $B$ it is generally irrelevant who he gets the money from as long as he receives it at the interest rate he promised to pay.

Paragraph 1 does not only refer to supervening death but also to supervening incapacity because in many European legal systems death and incapacity have historically been considered as equivalents with regard to the effects on pending offers. It has been pointed out above, that this equivalence is no longer justified since incapacity cannot be relevant at all for the termination of an offer. This is why the second paragraph exclusively refers to death. Incapacity does not affect the personality of the parties. It might only raise questions which are best dealt with under the rules on the protection of persons with mental disabilities.

The second paragraph states the exception to the general presumption in paragraph 1 , by referring to the intention which can reasonably be perceived by the other party. For this purpose, the second paragraph makes use of the formulation of Article 2:102 PECL and II-4:102 DCFR. In case of doubt an offer remains unaffected by death.

\section{Summary and conclusions}

1. The rule according to which the death of either party terminates a pending offer has its historical origins in medieval commentaries on Justinian's digest. The then applied will theory required a simultaneous declaration of intention (meeting of the minds) for the conclusion of a contract. This meant that in cases in which the offer was not accepted immediately, the offeror's intention had to persist until the moment of acceptance. The paradigm case for an offer not being immediately followed by the acceptance was an offer sent by letter. Considering the requirement of persistence of the offeror's intention, the medieval commentators assumed that the letter was nothing else but an instrument that allowed the offeror to speak to the offeree at the moment of acceptance. The logical consequence of this conception was of course that whenever the offeror had died or had become unsound of mind before the offeree accepted, the offer was terminated, since the letter could no longer serve as an instrument to express the offeror's intention.

2. Notwithstanding the fact that the requirement of a simultaneous declaration of intention (simultaneous meeting of the minds) was abandoned, the 'dying' offer rule survived in many modern European legal systems. It was, however, adapted and transformed into a rebuttable presumption. In some countries like Italy, Spain, and England offers are generally presumed to lapse, except in cases in which the personal identity of either party turns out to be generally irrelevant for the future contract. In Germany, Austria, the Nether- 
lands and Portugal, on the other hand, the general presumption that offers remain unaffected by the death of the offeror does not apply when the offeror's contrary intention can be presumed from the objective meaning of the offer considering the circumstances which the offeree could have reasonably known.

3. The solutions adopted in different European legal systems show a common fundamental principle according to which only those offers should be terminated by death in which the personality of either party was essential for the future contract. The existing divergences regarding the general initial presumption do not affect this basic rule. Thus, regardless of whether offers are generally presumed to lapse with the death of the offeror or not, the basic rule is always that only those offers are terminated which have been made with special attention to the personal identity of the offeror and/or the offeree.

4. The tenor of the general presumption (or prima facie rule) affects the distribution of the burden of proof. While in systems that adopt the 'dying' offer rule, the heirs of the offeree have to show the circumstances or conduct which induced a reasonable person to understand that the offer was not exclusively addressed to the deceased, under the 'surviving' offer rule the opposite burden lies on the offeror's heirs who have to show the circumstances or conduct of the offeror on the basis of which a reasonable offeree was able to understand that the offer was due to lapse with the offeror's death.

5. A future European contract law should contain a prima facie rule according to which offers do generally not lapse with the death of either party. Death by itself, in fact, is a contingency that is inconclusive as to the effects on a pending offer. It always depends on whether the personal identity of either party was essential for the future contract. Since in a modern economy contracts predominantly serve economic purposes and the relevance of the parties' personal identity is certainly the exception, the preferable standard rule seems to be (notwithstanding the French drafts) that an offer (or acceptance) is not generally considered to be personal, except in cases in which such (objective) intention can be ascertained. The nature of the transaction alone or a contrary (hypothetical) subjective intention of one party is not conclusive. Whether an offer or acceptance lapses with the death of either party ultimately depends on what can be inferred from the statements or conduct as they were reasonably understood by the other party. 